\title{
Influence of Cooperative Model Type Mind Mapping Picture Card to Activity and Learning Results IPS Students Class IV SDN Keboansikep 2 Gedangan Sidoarjo
}

\author{
Erna Wijayanti \\ Universitas Negeri Surabaya \\ Surabaya, Indonesia \\ ewijayanti18@gmail.com
}

\begin{abstract}
This study aims to find out the influence of cooperative learning model Mind Maping Type Fibers Picture Card on learning activeness and learning outcomes IPS siswas kelase IV SDN Keboansikep 2. This study was carried out in SDN Keboansikep 2 Gedangan Sidoarjo with research subjects of students of class IV A and IV B on academic year 2018/2019. The type of research conducted is experimental research with the form of research design Non equivalent control group design. The instrument used to collect data is an observation sheet to measure learning activities and a test sheet to measure learning outcomes. Grain of learning result variable has been tested through validity test using Product moment correlation and reliability test using Alpha Cronbach's with valid and reliable result. Test Normality data using Kolmogorov Sminorv, is test homogeneity and hypothesis testing using the independent formula Sample $t$ test with the results of both classes are normal and homogeneous distributed. The data that have been collected are analyzed by $t$ test analysis by using computer with series program of statisyic program (SPSS Version 17). The result of hypothesis test shows that the activity and the result of student learning in the experimental class is better than the control class. In order to support this research, it was developed by using picture cards and using descriptive method to 60 students consisting of control class and experiment class. The results show that there are four things that affect, namely the role of students, learning outcomes, learning process and learning media used. From these results, we find that almost $70 \%$ of the media used fits perfectly with students' thinking ability. This is because during the learning process the students gain experience in making Mind Maping with an image card. So that activity and result learn student increase. Thus it can be concluded that the model of cooperative learning type Mind Maping with image card on the influence of activity and student learning outcomes significantly.
\end{abstract}

Keywords-Mind mapping; picture card; activities and learning outcomes

\section{INTRODUCTION}

IPS education should really be able to guarantee the efforts of debriefing, strengthening the ability and basic skills for students to become good citizens as mandated by the 1945
Constitution. The purpose of IPS education in primary schools is to educate and equip the competence to students to be able to develop self according to talents, abilities and skills possessed. For that we need a learning strategy that becomes the liaison to achieve that goal. Learning strategy is closely related to the model of learning in managing learning activities to deliver learning materials in a consistent and systematic so that the expected standard of competence can be easily understood by students effectively and efficiently.

In fact, to implement meaningful IPS learning is difficult. This is because IPS material that is too complex and always follow the development of the time so that sometimes makes the students difficult to understand the material. IPS Subjects at Elementary School level are formally established using the Integrated IPS learning model. The problems that arise are Basic Competence (KD) in Curriculum Subjects IPS not yet structured in an integrated manner. Although the Subject Subject is no longer known, the KD in the content standard still shows explicitly the substance of each sub subject. Impacts in teaching teachers tend to follow curriculum based on existing sequences so that teacher-centered learning, in teacher learning process also has not presented an interesting learning media, such learning is called conventional learning. As a result many students are less active in the learning process so that students understanding of IPS lessons becomes decreased and impact on student learning outcomes become low. The problem is supported by quantitative data from daily test result of fourth grade students of SDN Keboansikep 2 Gedangan Sidoarjo obtained the data of the majority of students get low score. This becomes an interesting thing to do research.

Model of cooperative learning type Mind Maping berbedia image card is a model of learning involving students since planning, both in determining the topic and how to learn it. In addition, this model learning emphasizes student activity to complement the mind map with the image card. Not only that students also innovate to collect as many image cards as according to the topics being studied. This will affect the learning activities and student learning outcomes that are expected to increase. 
Based on this background and to obtain a more objective picture of the activity and learning outcomes, the researcher should conduct a research entitled " The Influence of Cooperative Learning Model Type Mind Maping Graphic Image on Activities and Learning Outcomes IPS Students Class IV SDN Keboansikep 2 Gedangan Sidoarjo

Based on the findings of the problem and the foundation of the thinking, can be formulated research problems as follows: (1) How the level of learning activeness of IPS fourth grade students SDN Keboansikep 2 Gedangan Sidoarjo using model of cooperative learning type Mind Maping berbedia image card ?. (2) Is there any influence of cooperative learning model of Mind Maping type with image card on IPS learning result of fourth grade students of SDN Keboansikep 2 Gedangan Sidoarjo ?.

Cooperative learning can be interpreted as learning together, interbreeding with one another, and ensuring that everyone in the group can reach the goal or accomplish the tugase that has been coordinated together [1]. Meanwhile, according to (Hamdani 2011: 165) cooperative learning is a strategic pemajarang gapratega yang emphasize on the sikapa satau perilakur bersereke berseer or bounce in the fellow in the structure of regular cooperation in the group. Based on these two opinions can be concluded that cooperative learning is a model of learning which is able to train students to cooperate with their friends to achieve common goals[2].

Mind Maping is one of cooperative learning. Mind Mapinga's strategy of learning is developed as a defective method for developing ideas through the maps. The famous Mind Maping initiator is Tony Buzan [3]. In order to make aMind Map comply with kBuzan, one can begin by writing the ultimate connector in the middle of the dane's hierarchy from which it can develop in any direction to create a kind of diagrammed diagram of key words, phrases, concepts, facts , and pictures. Tony Buzan developed a model of learning Mind Maping type or mind map based on the workings of the human brain in storing the information obtained. An information storage system in the human brain is collected in nerve cells that branch off as in the concept of making Mind Maping. If the human brain receives the same information as the workings of the brain, then all information can be received easily so that the learning material can be easily understood by the students. According to Riyanto. Y [4] Mind Maping type is very appropriate used in the learning process because to analize initial knowledge possessed students and acquire new knowledge in accordance with student learning experience to generate alternative answers.

According Riyanto Orphans (2014: 275) As for the steps in making Mind Maping is as follows:

a. Students are informed about the competence to be achieved

b. The teacher expresses the main concept that contains the alternate answers and the students will respond.

c. Students are formed into several discussion groups

d. Each group inventoried / recorded an alternative answer to the discussion. e. Each group presented the results of the discussion. Teachers take notes on the board and classify as needed.

f. Based on the data on the board students are asked to conclude or provide a comparison according to the concept provided by the teacher.

The application of cooperative model of Mind Mapping type in classroom learning has many advantages. Here are the advantages of the Mind Maping type cooperative model;

a. Provides convenience for students to see the overall picture of the material.

b. Helps the brain to recall the relevance of learning materials.

c. Facilitate our brain in receiving new information

d. It takes a short time to relearn

e. The presentation of Mind Mapping is more interesting because it is accompanied by pictures and colors

With the implementation of cooperative learning model type Mind Maping media image card in the learning process will affect the activity and learning outcomes IPS fourth grade students SDN Keboansikep 2 significantly increased.

\section{METHOD}

Type of quantitative research in the form of experiments, because the method of experimental research can be interpreted as a research method used to find the effect of certain treatment against others in controlled conditions[5]. The researcher uses experimental design because the variables can be selected and the other variables can influence the experimental process and can be strictly controlled. In this case means giving treatment to the research subjects ie fourth grade students SDN Keboansikep 2 Gedangan-Sidoarjo. This study aims to determine the effect of the model of cooperative learning model type Mind Maping image media card kebadapa effectiveness and learning results of students class IV SDN Keboansikep 2 Gedangan -Sidoarjo.

One of the special features of experimental research is the treatment imposed on the subject or object of the study. In this research, experimental research is done because to examine the existence of causal relationship between dependent and free variable through cooperative learning model of Mind Maping type with image card[6].

Researchers will pilot their research into controls and experimental classes. In the control class will apply conventional learning (not treated) and in the experimental class will apply cooperative model of Mind Maping type with image card.

The research design used the nonequivalent control group design. According to Sugiyono[5], stated that nonequivalent control group design is similar to pretest-posttest control group design, only in this design the experimental group or control group is not randomly selected.

This research has two groups: control group and experiment group. This control group will be a comparison for the experimental group, and this experimental group will be 
given the model of cooperative learning model of Mind Maping type with image card, while the control group is given lecture method[7].

The purpose of this data analysis is to know whether there is influence of cooperative learning model type Mind Maping with image card in order to increase activity and learning result of IPS student of class IV-A in SDN Keboansikep 2 year lesson 2017-2018. To measure the data that support the achievement of the objectives of this study, will use the analysis data statistics with $t$ test. This research begins by doing pretest as a preliminary test to know the intake of students, then it will be subject to treatment in a certain period to analyze activity and learning outcomes. Posttest is done as a final test to determine the level of understanding of students on the sub-theme Cultural Diversity My Nation. The basis for decision-making is based on a comparative $t$-count with t-table.

\section{RESULT AND DISCUSSION}

Based on the research it can be seen that the two classes tested are control class with conventional learning model and experimental class with cooperative learning model of Mind Maping type with image card. From the table obtained a significant value of each of 0.605 . The test group has a significant value of 0.05 . So it can be concluded that the learning result data is normally distributed.

Based on these results, it is evident that the average of student learning outcomes in the experimental class is significantly better. This means the activity and learning outcomes of students who follow cooperative learning type Mind Maping berbedia image card better than the results of student learning following the conventional learning. With significant less than 0.05 then Ho is rejected and Ha accepted.

So the result of fourth grade students of SDN Keboansikep 2 on sub theme of Cultural Diversity with model of cooperative learning type Mind Maping different card image higher significantly compared with conventional learning result.

\section{CONCLUSIONS AND SugGestions}

Based on the discussion of research results can be concluded that the model of cooperative learning type mind maping media card image has an influence on activity and learning outcomes[1]. This can be seen from the analysis that has been done. Students are able to identify any information it receives and then evaluate and then summarize it systematically. Students are also able to make simple notes in the form of Mind Maping compared to conventional learning that can only make regular notes.

In the models of Mind Maping modeled learning, student image cards appear more active in interacting with their friends. While in conventional learning students tend to be passive. Model of cooperative learning type Mind Maping different card image also affect on student learning outcomes. this is because students have high learning activities so that the learning outcomes increase.

From both analysis it can be concluded that cooperative learning of Mind Maping type with image card has more influence than conventional learning. Cooperative learning type Mind Maping with image card can increase learning activity and fourth grade student learning result SDN Keboansikep 2 Gedangan Sidoarjo.

\section{REFERENCES}

[1] J. M. Asmani, "Tips Efektif Cooperative Learning," Yogyakarta DIVA Pers, 2016.

[2] E. Solihatin, "Cooperative Learning Analisis Model Pembelajaran IPS," Jakarta Bumi Aksara, 2007.

[3] T. Buzan and B. Buzan, "Memahami Peta Pikiran: The Mind Map Book," Batam: Interaksa, 2004.

[4] Y. Riyanto, "Paradigma Pembelajaran.” Jakarta: Kencana, 2009.

[5] H. Sugiyono, "Metode kualitatif dan kuantitatif," Cetakan ke-23. Alf Bandung, 2016.

[6] A. S. Sardiman, “dkk.(2003)," Seri Pus. Teknol. Pendidik. no 6, media pedidik-an, pengertian, Pengemb. dan pe-manfaatannya.

[7] H. Isjoni, "Cooperative Learning efektifitas pembelajaran kelompok," Bandung Alf., 2013 